\title{
コメント:ジェンダー平等によって 雇用崩壊を防ぐ
}

浅倉むつ子

\section{はじめに}

「雇用崩壊とジェンダー」をめぐる日本学術 会議の公開シンポジウムにおいて、竹信報告は、 「主婦パートと学生アルバイトは小遣い賃金で よい」という差別を長らく受けてきたが、その 差別の構造が非正規や間接雇用の労働者の急増 と人材の劣化をもたらしたこと、それにもかか わらず、日本の法制度にはこれを解決する仕組 みがほとんどないことを鋭く指摘した。ジャー ナリストとして培った的確な分析力で、日本の 労働者の現状を包括的に浮き彫りにした報告 は、会場から共感をもって受け止められた。

一方、中野報告は、性別役割分業を土台に差 別を構造化し、税・社会保障制度を包括したレ ジームとして完成された「日本型雇用システム」 の問題点を、法的な観点から明らかにした。均 等待遇をめぐる法が非正規雇用差別に対して 有効に機能しないのは、均等のための比較が「雇 用管理区分内」に限定されているためであり、 これを解消するには「徹底した差別撤廃のため の法制度の実現が不可欠だ」という。非正規労 働をめぐる複雑な法改正の内容についても、数 多くの労働事件を扱ってきた実務家としての 経験をもとに、簡潔で鋭い分析が加えられた。

私は、以上の二報告に関わって、労働法の観 点からいくつかの補充的なコメントを行うこ とにしたい。

\section{人々の尊厳と価値を尊重する社会を}

「日本型雇用システム」が日本特有の「雇用 管理区分」を内在化させてきた、という中野報 告による批判的観点を、私も共有しておきた い。日本企業は、そもそも非正社員（非正規労 働者）を正社員の長期安定雇用を保障するため の不可欠な存在として位置づけつつ、両者の処 遇をまったく異なる管理下においてきた。しか し1990年代頃までは、正社員と非正社員の著 しい差別的処遇は、非正社員を供給してきた「男 性稼ぎ主型家族」の存在によって不可視化さ れており、それだけに、これが日本を摇るがす 問題だという意識は社会において希薄であっ た。しかし今や、「男性稼き主型家族」は虚像 化し、非正社員の稼ぎに頼る家族が増え、一方、 雇用の複線化、多様化、流動化、規制緩和が進 み、正社員にとっても決して安泰ではない時代

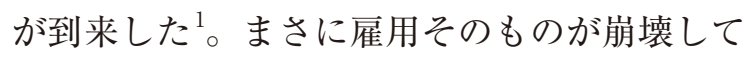
いるのである。

そのような状況の中でも、労働法における ジェンダー関連の法改正は比較的頻繁に行わ れてきた。しかしそれら法改正をもたらした主 たる要因は、「規制緩和」と「少子化対策」で あった。日本と異なり、他の国における雇用平 等政策の背景には、労働者にとって公正で暮ら しやすい社会像の追求等、独自の理念が示され ている。イギリスの労働法学者、サンドラ・フ レッドマンの表現を借りれば、平等の実現は、 
(1)すべての人々の尊厳と価值の尊重、(2)コミュ ニティ内部への受容・承認、(3)社会からの排除 が及ぼす不利益のサイクルの切断、(4)社会への 完全参加のために、率先して取り組まれなけれ ばならない課題であり、諸国の政府は、少なく とも理念としてそれらの課題を追求してきた といえよう ${ }^{2}$ 。ところが残念ながら、日本の労 働政策を牽引してきたものは、このようなある べき社会像のために掲げられた理念ではなく、 むき出しの経済効率性や企業の競争力強化で あった。その場合、ジェンダー平等は、経済効 率性に反しないかぎりという条件つきで実現 されるものとして、後景に退けられてきた。

社会におけるジェンダー平等理念の脆弱性 を反映して、男女雇用機会均等法（以下、「均 等法」という）は1997年の法改正後も、「雇用 管理区分」ごとに差別的取扱いを判断するとい う指針を維持しており、雇用管理区分が違う男 女間では差別を争うことができない。すなわち 日本では、均等待遇原則といっても、企業が設 定する「雇用管理区分」の枠内での均等であり、 「雇用管理区分」ごとの比較にとどめられてい るのである。しかし、総合職／一般職、正規／ 非正規の区分を超えた比較がなされないかぎ り、ジェンダー平等原則は企業の雇用管理を是 正する効果をもちえない。したがって、もっと も高みにある理念として、まず、ジェンダー平 等を組み込んだあるべき社会像の実現を優先 させることが必要である。私なりに表現するな らば、人々の尊厳と価值を尊重する社会という
ものを提示しつつ、そのための労働政策が語ら れなければならない。

\section{差別の法的定義が必要}

竹信報告は、「賃金差別」を「賃金格差」と 言い換えるマスコミの報道姿勢を批判すると ころから始まった。なぜ人々は、賃金差別を賃 金格差と言い換えるのを好むのだろうか。それ は、性別を理由とする「差別」は違法であり是 正されなければならないが、賃金の「格差」は 社会における事実上の男女差を反映した合理 的なものにすぎず、企業責任を問うものではな いからであろう。

もちろん現在では、「差別をしてはいけない」 と考える人は増えている。にもかかわらず、人々 は、差別という事実の存在を簡単には認めたく ないのである。それゆえ日本社会では、差別を 違法なものとして禁止する立法よりも、ゆるや かに格差を縮小しながら機会均等を実現して いこうとする立法が好まれる。しかし、平等実 現の重要性や差別がもたらす悪影響を直視す れば、まずは「差別は違法である」と宣言し、 それを追放する立法の存在が不可欠とされな ければならない。

ちなみに現行法としては、均等法と労働基準 法が雇用における性差別を禁止している。とこ ろが、これらの法律には「差別」の定義がない。 人々が「これが差別だ」と説明するための法的 な根拠が明文化されていないのである。これで 
は、「差別とは何か」という共通の理解を社会 に定着させることは難しい。2009年8月に国連 の女性差別撤廃委員会は、日本に対する総括所 見において、「女性に対する差別の定義を国内 法に完全に採り入れるために緊急の措置を講 じ、次回の報告においてこの点に関する進渉状 況を報告すること」を求めた ${ }^{3}$ 。ちなみに、国 連の女性差別撤廃条約に扮ける性差別の定義 は、「性に基づく区別、排除又は制限であって、 政治的・経済的・社会的・市民的その他のいか なる分野においても、女性が男女の平等を基礎 として人権及び基本的自由を認識し、享有しま たは行使することを害しまたは無効にする効 果または目的を有するものをいう」とある。こ の差別の定義は、国連の他の人権条約（たとえ ば人種差別撤廃条約や障害者権利条約）でも採 用されており、女性差別撤廃委員会は、他国の レポート審査においても、繰り返し、この差別 の定義を国内法に導入することの重要性を指 摘している ${ }^{4}$ 。この定義には、直接性差別、間 接性差別の禁止が包括されている。しかしなが ら日本政府は、その後もこの総括所見の求めに は応えていない。

以上の経緯からも、均等法の改正によって、 条約に則った「性差別の定義」規定を新設する ことが必要である。ただし、均等法は2006年 の改正において「女性差別」禁止立法から「性 差別」禁止立法へと変化したため、性差別の定 義はあくまでも男女双方に対する差別を禁止 する文言になる。

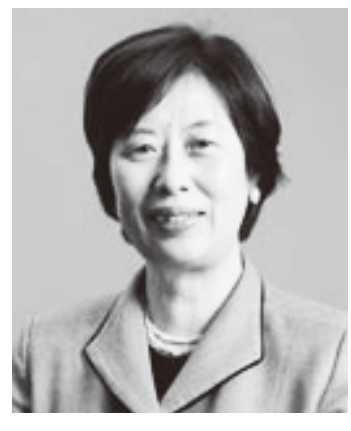

\section{PROFILE}

浅倉むつ子

(あさくら むつこ)

日本学術会議第一部会員、早稲田大

学大学院法務研究科教授

専門 : 労働法、ジェンダー法

\section{同一価値労働同一貨金原則の実現を}

竹信報告も、中野報告も、今日の雇用崩壊へ の対抗手段として、同一価值労働同一賃金原則 の実施を提案した。竹信報告は、「恣意的な評 価で特定の特性をもった人をカテゴリーの中 に押し込め、働き手を無力化してしまう賃金」 を批判しつつ、労働価值の評価を公正にすべき だと主張し、中野報告も、「職務の価值評価に よることを明確に」すべきだと強調する。両報 告とも、現在の多くの日本企業が実施している 「職能資格給」制度には批判的であり、代わりに、 「客観的で性差別のない、仕事や職務にみあっ た賃金制度」を日本で確立することが、反差別 の制度的仕組みとして有効だという。この点に ついても私は同感する。労働や職務に見合った 賃金を支給するという手法が、もっとも労働者 の被差別感を縮小する手立てであろう。

もちろん、法制度として、日本の企業に特定 の賃金制度を強制する、などということはでき ようもない。そこで、私たちがある共同研究を 通して2010年に提言したことを、ここで紹介 しておこう。それらは以下の二点に集約するこ 
とができる ${ }^{5}$ 。

第一点は、同一価值労働同一賃金原則を日本 の法制度のなかに明文化することである。まず、 労基法 4 条の現行規定（賃金に関する性差別の 禁止）を 4 条 1 項として維持しながら、2項を 新設して「同一労働・同一価值労働の男女に同 一賃金が支払われていない場合には、性差別が 推定される」と規定することを提案する。もし 労基法がこのように法改正されれば、賃金差別 訴訟で、原告が比較対象者と同一価值労働であ ることを主張する事案において、裁判所は、同 一価值労働同一賃金原則に則った法的判断を 行うよう義務づけられる。もっとも「同一価值 労働」の男女に同一賃金が支払われていないこ とは直接ないし間接の「性差別の推定」にすぎ ないから、使用者は当該賃金格差の合理性・正 当性を反証することが可能である。

第二点は、以上のような法改正をしたうえ で、同一価值労働同一賃金原則を実施する具体 的なシステムの提案であり、それらには、(1)職 務評価システムの構築、(2)独立専門家制度の導 入、(3)平等賃金レビューの実施という三つの具 体策が含まれる。

一番目の具体策である職務評価システムの 構築という提案は、ILO も提唱する汎用性の高 い「得点要素法」という手法によって、同一企 業に雇用される労働者間の職務比較のために、 「知識・技能」「責任」「負担」「労働環境」とい う四つのファクターによって職務の価值を評 価し、点数を算出し、その点数を賃金に反映す
るジェンダー中立的な職務評価のやり方を実 践的に社会に示していく、ということである。 厚生労働省も2012年11月に、それ以前のガイ ドライン（これは単純比較法であった）を改訂 して、『パートタイム労働者の納得度を高め能 力発揮を促進するために一一要素別点数表に よる職務評価の実施ガイドライン』を作成し、 公表した。この厚生労働省のガイドラインの中 身については、なお批判もあるものの、政府段 階でも、職場における賃金制度に労働の価值を 比較する手法を採り入れること、その手法は単 純比較法ではなく要素別比較法であること、そ れをパートタイム労働者と正社員の均等・均衡 待遇に反映させようとしていることが、現在で は、方針として打ち出されている。このことを 各企業は肝に銘じる必要があろう。

二番目の具体策である独立専門家制度の導 入提案とは、賃金差別紛争にかかる特別な手続 きを労働審判法に導入して、労働審判委員会が 申立人と比較対象者の職務の価值の異同を評価 する能力をもつ独立専門家に、報告書の作成を 依頼できる仕組みを導入すべきという提案であ る。三番目の具体策である平等賃金レビューと は、イギリス等の国で行われているシステムを 参考に、日本でも、一つの企業の中で同一価值 労働の男女間に重大な賃金格差がある場合に は、その原因をつきとめて、企業が平等賃金の アクション・プランを策定・実施するように奨 励するという仕組みを導入すべき、という提案 である。これら具体策は、仕事・職務中心の賃 
金制度の実現にとって役立つであろう。

\section{障害者の権利運動との共闘を}

均等法は、あと 2 年で制定 30 周年を迎えるが、 この法律をめぐる改正論議は盛り上がりを欠 き、雇用における男女格差にも改善の傾向はみ られない。

一方、障害者権利条約の批准を前に、現在、 障害に基づく差別禁止立法の検討が進みつつ ある。内閣府では、障害者政策委員会の下に設 けられた「差別禁止部会」が、民主党政権下 の 2012 年 9 月に「意見」を公表し、雇用のみな らずあらゆる分野における障害差別を包括的 に禁止する障害差別禁止法の立法化を提案し た。また、厚生労働省は、2013年3月に、障害 者雇用促進法の改正を通じて障害者差別を禁 止する意向を示している（労働政策審議会障害 者雇用分科会「今後の障害者雇用施策の充実強 化について」)。今後、内閣府と厚生労働省の意 見の調整が図られなければならないが、これら の議論の中で、雇用差別全般にも通底する差別 概念の掘り下げが行われていることに注目し たい。内閣府の差別禁止部会意見は、障害に基 づく「直接差別」「間接差別」(外形的には中 立の基準、規則、慣行であってもそれが適用さ れることにより、結果的には障害をもつ者に不 利益が生じる場合)、「関連（起因）差別」(障 害に関連する事由を理由とする区別、排除、制 限等の異なる取扱い) という三つの差別類型と
並べて、第4類型の差別として「合理的配慮の 不提供」を示し、具体的な事例も掲げている。 「雇用崩壊とジェンダー」のシンポジウムで、 中野報告は「合理的配慮の不提供」という差別 類型の重要性を語ったが、その発想はまさに、 障害差別に着目するところから得られるもの である。

ここからもわかるように、日本社会におけ る雇用差別の撤廃をより内実のあるものにす るには、女性と障害者が相互に協力していくこ とが非常に効果的である。性差別と障害差別に は多くの共通点があり、相互に議論することに よって禁止されるべき差別概念を理論的に深 めることができる。また、女性であり障害者で あるという二重の差別は、複合差別概念という 新たな発想を私たちに気づかせてくれる。障害 差別禁止法が立法化されれば、わが国ではじめ て、あらゆる分野を対象とする具体的な差別禁 止法が生まれることになり、ひいては、均等法 をめぐって膠着状態に陥っている感のある雇用 差別に関する議論をおおおいに活発化させるであ ろう。雇用崩壊を防ぎ、ジェンダー平等を推進 するためにも、ぜひとも、障害差別禁止法の成 文化と障害者権利条約の批准に期待したい。

注

1 浅倉むつ子「日本的雇用慣行と性差別禁止法理」ジェン ダー法学会編『講座ジェンダーと法〈第 2 巻〉固定され た性役割からの解放』(日本加除出版、2012年) 3頁以 下参照。

2 S. Fredman, Human Rights Transformed : Rights and Positive Duties, Oxford University Press, 2008, p.179.

3 第4回（第6次）日本政府レポート審議総括所見21項、 
22項、山下・辻村・浅倉・二宮・戒能『ジェンダー六法』 （信山社、2011年）16頁。

4 国際女性の地位協会編『コンメンタール女性差別撤廃条 約』(尚学社、2010年) 所収「第1条 女性差別の定義」(黒 岩容子執筆部分）参照。

5 森ます美・浅倉むつ子編著『同一価值労働同一賃金原則 の実施システム一公平な賃金の実現に向けて一』(有斐閣、 2010 年)。 